Brazilian Journal

of Chemical

Engineering

\title{
INFLUENCE OF HYDRAULIC RETENTION TIME ON HYDROGEN PRODUCTION BY TREATING CHEESE WHEY WASTEWATER IN ANAEROBIC FLUIDIZED BED BIOREACTOR - AN APPROACH FOR DEVELOPING COUNTRIES
}

\author{
Thiago D. Marques ${ }^{1}$, Williane V. Macêdo ${ }^{2}$, Fernanda S. Peiter ${ }^{2}$, Anna A. T. L. Bonfim¹ \\ Isabel K. Sakamoto' , Roberto A. Caffaro Filho ${ }^{1}$, Marcia H. Z. Damianovic ${ }^{2}$, \\ Maria B. A. Varesche ${ }^{2}$, Karina R. Salomon ${ }^{1}$ and Eduardo L. C. de Amorim ${ }^{1 *}$ \\ ${ }^{1}$ Universidade Federal de Alagoas, Centro de Tecnologia, Maceió, AL, Brazil. E-mail: eduardo.lucena@ctec.ufal.br - \\ ORCID: 0000-0002-7349-9055 \\ ${ }^{2}$ Universidade de São Paulo, São Carlos, SP, Brazil
}

(Submitted: February 13, 2019 ; Revised: May 4, 2019 ; Accepted: May 5, 2019)

\begin{abstract}
This study assessed the effect of hydraulic retention time (HRT) on biohydrogen production by dark fermentation using an anaerobic fluidized bed reactor fed with cheese whey synthetic wastewater. The reactor of $1.2 \mathrm{~L}$ was operated with an approximate carbohydrate concentration of $2800 \mathrm{mg} \mathrm{L}^{-1}$, and HRTs of $6,4,2,1$ and $0.5 \mathrm{~h}$. Acetic and butyric acids were the main metabolites produced in the reactor. The hydrogen production

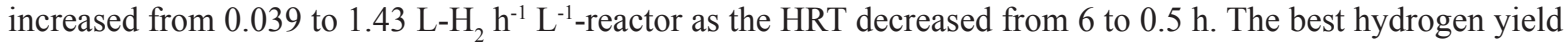
(HY) $\left(2.73 \mathrm{~mol}^{-\mathrm{H}_{2}}\right.$ mol-carbohydrate $\left.{ }^{-1}\right)$ and carbohydrate consumption $(81.02 \%)$ were achieved at a HRT of $6 \mathrm{~h}\left(12.34 \mathrm{~kg}^{-C O D ~ m^{-3}} \mathrm{~d}^{-1}\right)$ followed by the HY of $2.43 \mathrm{~mol}^{-\mathrm{H}_{2}}$ mol-carbohydrate ${ }^{-1}$ at a HRT of $0.5 \mathrm{~h}(163.02$ $\mathrm{kg}$-COD m $\mathrm{m}^{-3} \cdot \mathrm{d}^{-1}$ ). An increase in the influent $\mathrm{pH}$ in the operational phase 05 (HRT of $0.5 \mathrm{~h}$ ) favored hydrogen production despite the reduced carbohydrate conversion compared to phase 01 (HRT of $6 \mathrm{~h}$ ). In both conditions, the reactor presented the highest amount of acetic acid, indicating that the acetate route favored the hydrogen yield production. The HRT reduction led to an increase in microbial diversity, as evidenced by the ShannonWiener coefficient of 2.586, which corresponds to the operational phase with a HRT of $2 \mathrm{~h}$.

Keywords: Anaerobic fluidized bed reactor; Dark fermentation; Cheese whey wastewater; Hydrogen production; Hydraulic retention time.
\end{abstract}

\section{INTRODUCTION}

Hydrogen emerges as a clean energy source since its combustion produces only water, unlike fossil fuels combustion that generates unwanted greenhouse gases (Han et al., 2015). Hydrogen can be produced from non-renewable resources, such as oil, natural gas and coal, or from renewable sources, such as biomass (Tapia-Venegas et al., 2015). Biological processes using biomass waste as substrate are environmentally friendly because they present low energy requirement and contribute to $\mathrm{CO}_{2}$ global reduction (SilvaIllanes et al., 2017). Usually, biological processes to obtain hydrogen encompass the photo-production process (direct or indirect bio-photolysis and photofermentation) or the dark fermentation (Tapia-Venegas et al., 2015).

In dark fermentation processes, hydrogenproducing anaerobic microorganisms break down the carbohydrate-rich substrates (Ghimire et al.,

\footnotetext{
* Corresponding author: Eduardo L. C. de Amorim - E-mail: eduardo.lucena@ctec.ufal.br
} 
2015). Conversion of the various complex organic wastes to produce hydrogen occurs at high rates via butyric acid-type, propionic acid-type, or ethanol-type fermentation (Liu et al., 2015). Different metabolites can be produced such as acetate, butyrate, propionate and ethanol. The direction of the metabolic pathway is determined by the environmental conditions of the fermentation process. Temperature, $\mathrm{pH}$ and the dynamic of the microbial community can affect the fermentation process (Ziara et al., 2018).

Dairy industry wastewater is commonly employed as a substrate for dark fermentation processes because it is rich in carbohydrates and readily biodegradable. Various researchers have assessed different operational parameters and reactor configurations to produce hydrogen from cheese whey and lactose wastewater. Carrillo-Reyes et al. (2012) investigated different operational strategies and inoculum structure (granules and disaggregated granules) during the start-up of four up-flow anaerobic sludge blanket hydrogenogenic reactors. Azbar et al. (2009) investigated the effects of hydraulic retention time and organic loading rate (OLR) variations on the $\mathrm{H}_{2}$ production using a continuous stirred tank reactor. Yang et al. (2007) also studied the effects of HRT. The authors used batch and continuous reactors to evaluate microbial communities under mesophilic conditions. Castelló et al. (2009) operated an UASB reactor to examine the influence of organic loading rates, displaying the links between microbial community and reactor performance. Rosa et al. (2014) evaluated different ratios of carbon sources in the fermentation of cheese whey and glucose as substrates for hydrogen and ethanol production in continuous reactors. Ottaviano et al. (2017) analyzed an anaerobic fluidized bed reactor (AFBR) to produce hydrogen under thermophilic conditions $\left(55^{\circ} \mathrm{C}\right)$ continuously. They concluded that the metabolic pathway of hydrogen production was strongly influenced by the concentration of substrate and the organic loading rate. Despite the various researches evaluating the use of dairy industry effluent in dark fermentation reactors, parameters such as hydraulic retention time must be further investigated to identify the possible influences on the behavior of the process.

Among the innumerous possibilities of reactor configuration for dark fermentation processes, anaerobic fluidized bed reactors stand out as an interesting alternative for bioenergy production (Amorim et al., 2012, 2009, 2014; Ottaviano et al., 2017; Silva et al., 2019). AFBR advantages include high OLR and short HRT, fluidization reduces the possibility of reactor clogging and the support medium provides large surface areas for the formation of biofilms. Besides that, the intense movement and friction between the particles prevent excessive biofilm formation and promote the transfer of substrates, nutrients and metabolic products across the biofilm (Amorim et al., 2014; Inui et al., 2010).

On account of the above, the aim of this study was to observe the effect of hydraulic retention time (HRT) on biohydrogen production using an anaerobic fluidized bed reactor (AFBR) fed with cheese whey synthetic wastewater and operating at mesophilic temperatures.

\section{EXPERIMENTAL PROCEDURES}

\section{Inoculum and fermentation medium}

The inoculum used in this experiment was sludge from an UASB reactor treating domestic sewage. Before inoculation, the sludge was subjected to a heat treatment which consisted of $10 \mathrm{~min}$ heating at 90 ${ }^{\circ} \mathrm{C}$. This procedure is important to inactivate the $\mathrm{H}_{2}$ consumers and harvest endospore-forming anaerobic bacteria (Maintinguer et al., 2008) followed by a rapid cooling to room temperature. The inoculum was pumped into the reactor and recirculated for 48 hours with no feeding. Table 1 presents the composition of the synthetic wastewater used, which contained approximately $2800 \mathrm{mg} \mathrm{L}^{-1}$ of cheese whey. According to Ottaviano et al. (2017), the referred concentration might favor the hydrogen production. The commercial cheese whey used as a carbon source was composed of carbohydrates $(82 \%)$, proteins $(15 \%)$, total fat $(2 \%)$ and salts $(1 \%)$.

\section{Support material}

Shredded tires with particle size ranging from 3 to $5 \mathrm{~mm}$ were used as the support material to propitiate biomass immobilization by microbial attachment. The support material was subjected to a chemical treatment performed three times to enhance surface area roughness (Barros and Silva, 2012) by immersing the particles in hydrochloric acid $(10 \mathrm{M})$ for 30 minutes and drying them at $40^{\circ} \mathrm{C}$.

Table 1. Experimental procedure of each operational phase.

\begin{tabular}{|c|c|c|c|c|c|}
\hline Phase & $\begin{array}{c}\text { Operational } \\
\text { period duration (days) }\end{array}$ & $\begin{array}{c}\text { HRT } \\
\text { (h) }\end{array}$ & 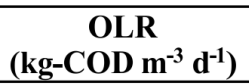 & $\begin{array}{l}\text { Influent carbohydrate } \\
\text { concentration }\left(\mathrm{g} \mathrm{L}^{-1}\right)\end{array}$ & $\begin{array}{c}\text { Daily feed } \\
\text { volume (L) }\end{array}$ \\
\hline 1 & 43 & 6 & 12.34 & $2.1 \pm 0.3$ & 6 \\
\hline 2 & 39 & 4 & 15.41 & $2.4 \pm 0.3$ & 9 \\
\hline 3 & 22 & 2 & 33.02 & $2.6 \pm 0.3$ & 17 \\
\hline 4 & 21 & 1 & 67.78 & $2.4 \pm 0.2$ & 35 \\
\hline 5 & 30 & 0.5 & 167.02 & $2.2 \pm 0.1$ & 69 \\
\hline
\end{tabular}




\section{Reactor (AFBR) and operating conditions}

Figure 1 shows a scheme of the anaerobic fluidized bed reactor (AFBR) system used. The reactor was constructed in acrylic, with a tubular section of $5.0 \mathrm{~cm}$ of internal diameter, height of $125.5 \mathrm{~cm}$, and working volume of $1.2 \mathrm{~L}$. The AFBR was fed with synthetic cheese whey wastewater. The experiment was conducted at room temperature aiming to incorporate the climate benefits of a tropical country such as Brazil $\left(26^{\circ} \mathrm{C}-33^{\circ} \mathrm{C}\right)$. The total liquid flow rate $\left(1.53 \mathrm{~cm} \mathrm{~s}^{-1}\right)$ was determined to be $30 \%$ higher than the minimum fluidization speed of the material support (shredded tire) $\left(1.18 \mathrm{~cm} \mathrm{~s}^{-1}\right)$ (Barros and Silva, 2012).

After inoculation of $48 \mathrm{~h}$ in batch mode with recirculation, the bioreactor was operated with a hydraulic retention time (HRT) of $6 \mathrm{~h}$. After reaching steady-state, based on a constant volumetric $\mathrm{H}_{2}$ production rate within a variation of $5-10 \%$ for $10-15$ days, the HRT was decreased progressively from $6 \mathrm{~h}$ to $0.5 \mathrm{~h}$. The reactor was operated for 155 days.

The daily feed volumes (Table 1) were determined according to the HRT, setting an additional $20 \%$ margin to avoid insufficient reactor load. Storage tank volume ranged from 7 to 70 liters to accommodate the feed volume. This reservoir was not kept under refrigeration to reduce the energy consumption applied to the experimental procedure and to approach a more realistic condition of wastewater treatment plants in developing countries. Its content was daily prepared and changed; therefore, no problems regarding the degradation of the wastewater were observed. As the feed was exposed to room temperature, natural fermentation caused variations in the influent $\mathrm{pH}$ in each operational phase. A gas-liquid separator was used at the effluent outlet to collect gaseous and soluble products separately.

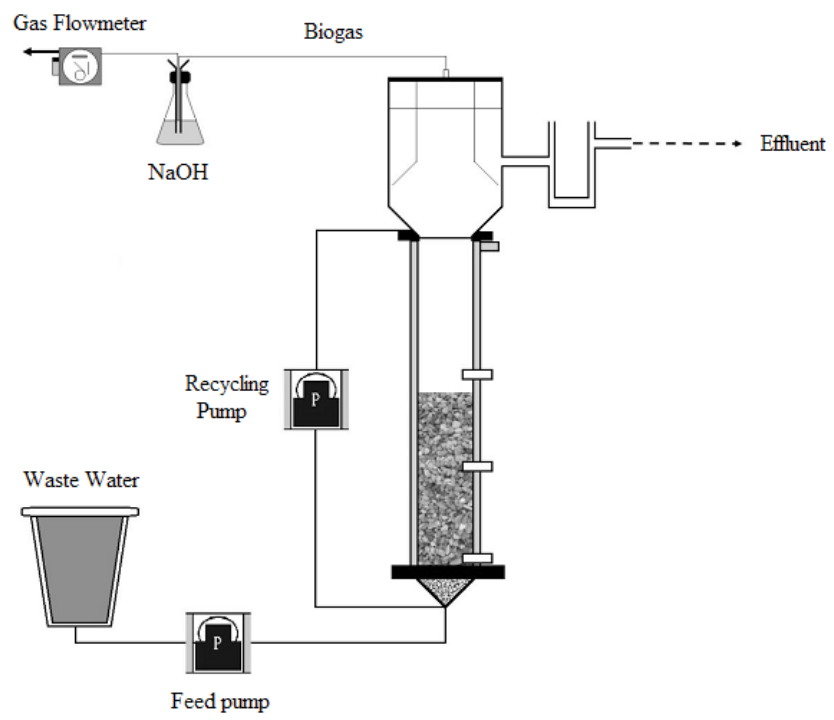

Figure 1. Schematic of the anaerobic fluidized bed reactor. From Amorim et al. (2014).

\section{Analytical methods}

The volatile fatty acid (VFA) and alcohol concentrations were monitored throughout the experiment and measured using a gas chromatograph (GC-2010, Shimadzu, Tokyo, Japan) equipped with a flame-ionization detector (FID), a HS20 headspace autosampler (Shimadzu, Tokyo, Japan) and a Carboxen Supelco-WAX column $(30 \mathrm{~m}$ high $\times 0.25$ $\mathrm{mm}$ i.d. $\times 0.25 \mu \mathrm{m}$ film thickness) (Maintinguer et al., 2008). The hydrogen production was monitored by gas chromatography (Shimadzu GC-2010 Plus) equipped with a thermal conductivity detector (TCD) $\left(230^{\circ} \mathrm{C}\right)$ and Carboxen \#1010 PLOT column (30 m x $0.53 \mathrm{~mm}$ ). A gas meter (Type TG1; Ritter Inc., Germany) was used to measure the amount of hydrogen generated (Amorim et al., 2012). The assessment of organic acids and ethanol was performed by chromatography (Shimadzu GC-2010 Plus) with a Flame Ionization Detector (FID Flame Ionization Detector), using, respectively, ethyl ether as the extracting solvent and the headspace extraction method and according to the procedure established by Adorno et al. (2014). The $\mathrm{pH}, \mathrm{COD}$, suspended and volatile solids analysis met the procedure described in Standard Methods (APHA, 1998), whereas the carbohydrates consume were obtained according to the procedure described by (DuBois et al., 1956). The $\mathrm{pH}$ and room temperature were monitored daily while the other parameters were monitored twice a week.

\section{Analysis of the microbial community}

The PCR-DGGE analysis (Polymerase chain reaction - Denaturing Gradient Gel Electrophoresis) was used to evaluate the microbial diversity on samples collected in all operational stages of the reactor by collecting for each stage a sample of support material. The genomic DNA extraction was performed in phenol-chloroform, according to the Griffiths et al. (2000) protocol. The fragments of 16S rRNA were amplified by Polymerase Chain Reaction (PCR) using the primers $968 \mathrm{FGS}$ and $1401 \mathrm{R}$ to the Bacteria domain (Nubel et al., 1996). PCR Amplification was performed in a DNA Thermal Cycler (GeneAmp PCR System 2400" - Perkin Elmer Cetus, Norwalk, CT) programmed for pre-denaturation at $94^{\circ} \mathrm{C}$ for 7 minutes and followed by 35 cycles of denaturation at $94^{\circ} \mathrm{C}$ for 45 seconds, annealing at $56^{\circ} \mathrm{C}$ for 45 seconds, extension at $72^{\circ} \mathrm{C}$ for 1 minute, final extension at $72^{\circ} \mathrm{C}$ for 10 minutes, and cooling to $4^{\circ} \mathrm{C}$.

For the Archaea Domain, PCR Amplification was also performed. In this case the 1100 FGC primers (Kudo et al., 1997) were used programmed in 35 cycles of denaturation at $94^{\circ} \mathrm{C}$ in 5 minutes, denaturation at $94^{\circ} \mathrm{C}$ for 1 minute, annealing at $55^{\circ} \mathrm{C}$ for 1 minute, extension at $72^{\circ} \mathrm{C}$ for $1 \mathrm{~min}$, final extension at $72^{\circ} \mathrm{C}$ for 
7 minutes, and cooling to $4{ }^{\circ} \mathrm{C}$. The separation of the amplified gene's fragments by PCR and Denaturing Gradient Gel Electrophoresis (DGGE) was conducted at a temperature of $60^{\circ} \mathrm{C}$ and constant voltage of $75 \mathrm{~V}$ for 16 hours, using denaturing gradient concentrations of $65 \%$ and $45 \%$.

Similarity coefficients were calculated for the different DGGE profiles obtained during the operational stages of the reactor and were presented graphically in a dendrogram and calculated based on Pearson correlation using the BioNumerics ${ }^{\circledR}$ software. The evaluation of the bacterial diversity in the reactor during the operational stages was performed by the application of the Shannon-Wiener diversity index $(\mathrm{H})$ calculated using the Past ${ }^{\circledR}$ software according to Abreu et al. (2010).

\section{RESULTS AND DISCUSSION}

Spearman's coefficients in Table 2 indicate strong correlation (value above 0.9 , in module) of HRT with some response variables: carbohydrate conversion, hydrogen production rate (HPR), acetic acid and ethanol molar concentrations.

\section{Carbohydrate conversion and hydrogen production rate}

The carbohydrate conversion reduced along with HRT, from $81.0 \pm 10.3 \%(6 \mathrm{~h})$ to $54.4 \pm 2.5 \%(0.5$ h) (Figure 2). Similarly, Silva et al. (2019) found a direct proportionality between HRT and carbohydrate conversion, using an AFBR to produce biohydrogen. Since low HRT entails high organic loading rates (OLR), the result indicates that organic matter overloading constricted the carbohydrate conversion. In general, high substrate concentrations and kinetic

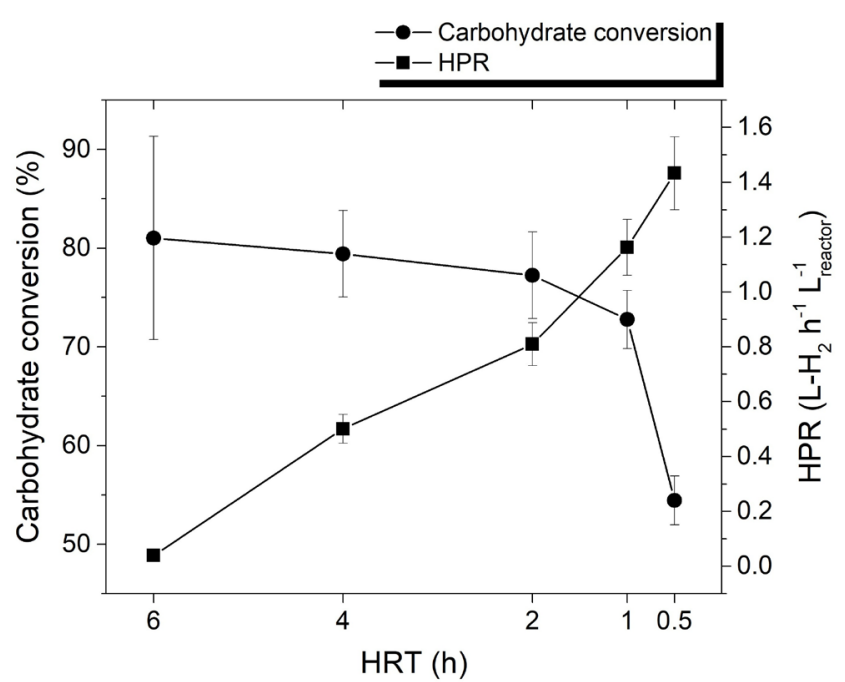

Figure 2. Carbohydrate conversion and hydrogen production rate.

limitation inhibit bacterial growth and its ability to consume substrate (Amorim et al., 2014; Guellout et al., 2018; Rai and Singh, 2016).

The hydrogen production rate (HPR) increased upon lowering the HRT (Figure 2), achieving an amount of $1.4 \pm 0.1 \mathrm{~L}^{-\mathrm{H}_{2}} \mathrm{~h}^{-1} \mathrm{~L}^{-1}$-reactor at $0.5 \mathrm{~h}(163.02$ $\left.\mathrm{kg}-\mathrm{COD} \mathrm{m} \mathrm{m}^{-3} \cdot \mathrm{d}^{-1}\right)$. The inverse correlation between HRT and HPR implies higher carbohydrate availability for conversion into $\mathrm{H}_{2}$ at lower HRT (higher OLR). Alexandropoulou et al. (2018), Carrillo-Reyes et al. (2014), Ottaviano et al. (2017) and Akhlaghi et al. (2017) also reported this behavior in their research, which corroborates the results in this article.

Phase 5 (HRT of $0.5 \mathrm{~h}$ ) had the maximum COD removal $(24.5 \pm 4.2 \%)$. Low COD removals in the phases 2, 3 and 4 can be associated with the formation of butyric and acetic acids, as explained in the next

Table 2. Operational parameters assessed during reactor monitoring in each operational phase.

\begin{tabular}{|c|c|c|c|c|c|c|}
\hline Phase & 1 & 2 & 3 & 4 & 5 & $\begin{array}{c}\text { Spearman's } \\
\text { coefficient } \\
\text { (correlation } \\
\text { with the HRT) }\end{array}$ \\
\hline HRT (h) & 6 & 4 & 2 & 1 & 0.5 & - \\
\hline pH affluent & $4.1 \pm 0.3$ & $4.2 \pm 0.4$ & $4.4 \pm 0.6$ & $4.3 \pm 0.3$ & $5.0 \pm 0.4$ & - \\
\hline pH effluent & $4.1 \pm 0.2$ & $4.1 \pm 0.2$ & $4.0 \pm 0.1$ & $4.1 \pm 0.2$ & $5.1 \pm 0.2$ & -0.70 \\
\hline Temperature $\left({ }^{\circ} \mathrm{C}\right)$ & 29.8 & 28.8 & 29.2 & 31.1 & 31.5 & - \\
\hline Average carbohydrate conversion (\%) & $81.0 \pm 10.3$ & $79.4 \pm 4.4$ & $77.3 \pm 4.4$ & $72.8 \pm 3.0$ & $54.4 \pm 2.5$ & 1 \\
\hline $\mathrm{HPR}\left(\mathrm{L}-\mathrm{H}_{2} \mathrm{~h}^{-1} \mathrm{~L}^{-1}\right.$-reactor $)$ & $0.04 \pm 0.01$ & $0.5 \pm 0.0$ & $0.8 \pm 0.1$ & $1.2 \pm 0.1$ & $1.4 \pm 0.1$ & -1 \\
\hline Hydrogen yield $\left(\mathrm{mol}_{2} \mathrm{~mol}^{-1}\right.$-carbohydrate) & $2.7 \pm 0.3$ & $1.6 \pm 0.2$ & $1.8 \pm 0.3$ & $1.7 \pm 0.3$ & $2.4 \pm 0.3$ & 0.10 \\
\hline Average COD removal $(\%)$ & $23.3 \pm 8.5$ & $19.6 \pm 10.6$ & $17.8 \pm 8.3$ & $19.2 \pm 5.8$ & $24.5 \pm 4.2$ & -0.10 \\
\hline Acetic acid concentration $\left(\mathrm{mmol} \mathrm{L}^{-1}\right)$ & 10.28 & 5.96 & 5.38 & 4.34 & 5.20 & 0.90 \\
\hline Butyric acid concentration (mmol L-1) & 3.32 & 3.40 & 5.35 & 5.12 & 2.66 & 0.10 \\
\hline Ethanol concentration $\left(\mathrm{mmol} \mathrm{L}^{-1}\right)$ & 1.14 & 1.30 & 1.25 & 2.00 & 1.39 & -0.90 \\
\hline n-butanol concentration $\left(\mathrm{mmol} \mathrm{L}^{-1}\right)$ & 0.00 & 0.00 & 0.17 & 0.17 & 0.00 & 0.20 \\
\hline Methanol concentration $\left(\mathrm{mmol} \mathrm{L}^{-1}\right)$ & 0.92 & 0.93 & 0.92 & 0.95 & 0.89 & 0.30 \\
\hline Caproic acid concentration $\left(\mathrm{mmol} \mathrm{L}^{-1}\right)$ & 0.00 & 0.00 & 0.24 & 0.33 & 0.00 & 0.10 \\
\hline $\mathrm{H}_{2}$ content in biogas $(\mathrm{v} / \mathrm{v} \%)$ & $25.8 \pm 9.0$ & $25.9 \pm 8.2$ & $10.8 \pm 3.4$ & $14.6 \pm 3.2$ & $52.4 \pm 8.5$ & -0.20 \\
\hline $\mathrm{CO}_{2}$ content in biogas $(\mathrm{v} / \mathrm{v} \%)$ & $74.2 \pm 9.0$ & $74.3 \pm 8.2$ & $89.2 \pm 3.4$ & $85.4 \pm 3.2$ & $47.6 \pm 8.5$ & 0.10 \\
\hline Shannon-Wiener index & 2.030 & 2.282 & 2.586 & 2.040 & 2.503 & - \\
\hline
\end{tabular}


subtopics. In a study using a fixed bed reactor with HRT of $24 \mathrm{~h}$ and OLR of $22 \mathrm{~g}^{-C O D ~ d}{ }^{-1}$, Perna et al. (2013) obtained $16.5 \%$ of COD removal and justified the low percentage by the presence of organic acids.

\section{Composition of soluble products}

Figure 3 displays acetic acid (33.60 - $65.63 \%)$ and butyric acid $(21.21-40.16 \%)$ as the principal metabolites produced in the reactor. Ethanol (7.30 $15.53 \%)$ and methanol (5.87 - 8.76\%) were produced in smaller amounts for all operational conditions. However, their presence may not be desirable in the reactor, as those routes consume substrate and do not produce hydrogen. Caproic acid $(1.79-2.55 \%)$ and n-butanol (1.24 - 1.33\%) occurred only in phases 3 and 4.

The inverse correlation between ethanol and acetic acid concentrations (Figure 4) points to the pathways which consume ethanol to produce acetic acid (Saady, 2013). Despite the strong correlation between HRT and ethanol production (Table 2), phase 4 (HRT of $1 \mathrm{~h})$ had a higher presence of this metabolite (2.0 mmol L $\left.{ }^{-1}\right)$. It suggests that ethanol type-fermentation occurred with a significant increase of ethanol in that phase. Ren et al. (2007) found similar behavior using continuous-flow acidogenic reactors to produce hydrogen. In their study, the ethanol yield surpassed that of the other metabolites when the pHdecreased further down to 4.6 , with a stabilized $\mathrm{pH}$ of 4.18 at the end of the analyzed stage.

Phase 4 (HRT of $1 \mathrm{~h}$ ) achieved the lowest acetic acid production of $4.34 \mathrm{mmol} \mathrm{\textrm {L } ^ { - 1 }}$. The higher productions of butyric acid $\left(5.35 \mathrm{mmol} \mathrm{L}^{-1}\right.$ and 5.12 mmol L$\left.)^{-1}\right)$ and caproic acid $\left(0.24\right.$ and $\left.0.33 \mathrm{mmol} \mathrm{L}^{-1}\right)$ occurred in phases 3 and 4 . These results indicate that a synthesis of butyric and caproic acids from ethanol and acetic acid occurred in the reactor (Barker et al., 1945). Since butyrate was the main product, fast acetic acid consumption prevailed over the use of ethanol in phases 3 and 4.

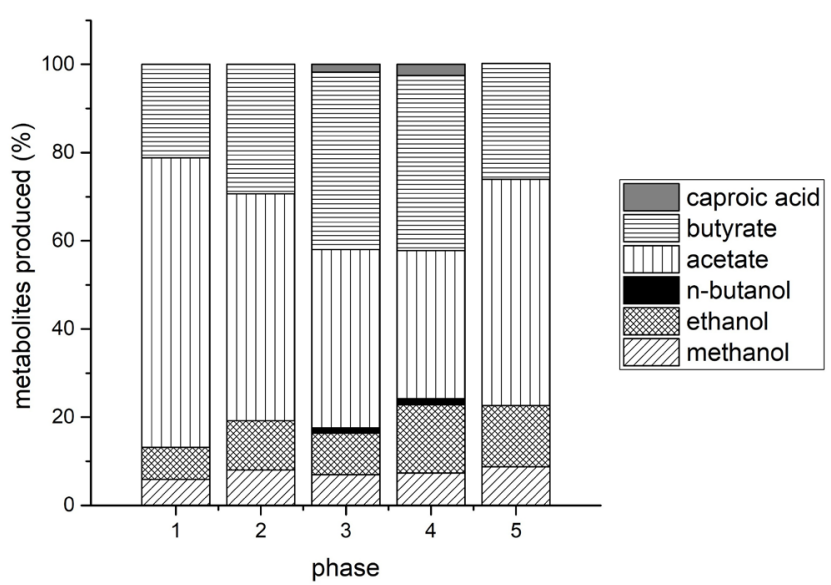

Figure 3. Metabolites produced in each phase.

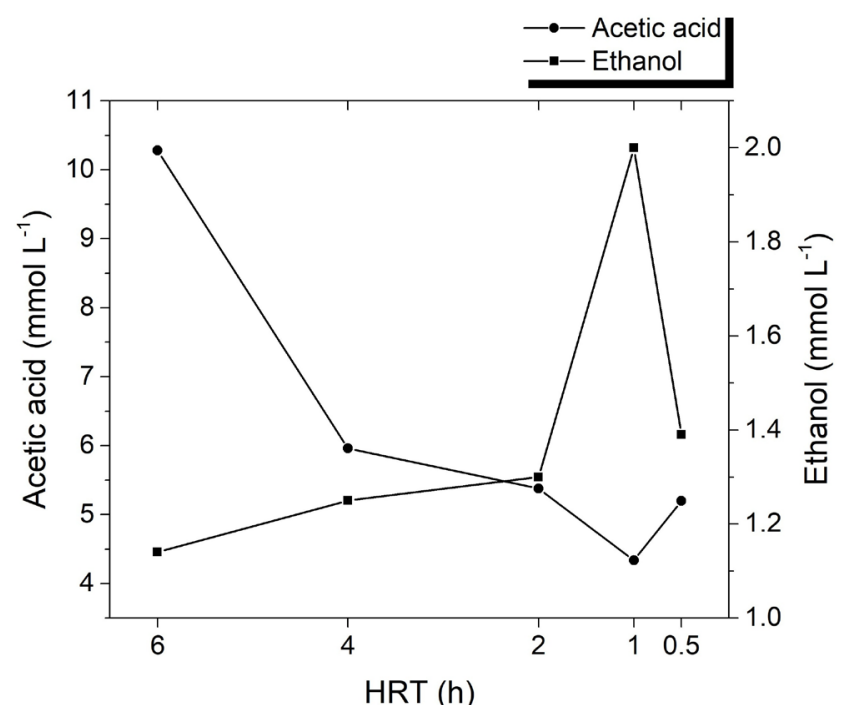

Figure 4. Variation of acetic acid and ethanol with HRT.

\section{Biogas composition and hydrogen yield}

Hydrogen and carbon dioxide composed the biogas generated (no methane was present) inferring the importance of heat shock to suppress hydrogen consuming species and enrich $\mathrm{H}_{2}$ producing bacteria (Rafieenia et al., 2018). Many researches have displayed the effectiveness of heat pretreatment of inoculum to inhibit methanogenic microorganism activity and improve hydrogen production in reactors (Ding et al., 2017; Lay, 2000; Maintinguer et al., 2015, 2008; Zhang et al., 2011). $\mathrm{H}_{2}$ content in biogas (Table 2) achieved $52.39 \%$ in phase 5 , and in the other phases, $\mathrm{CO}_{2}$ had higher percentages ( $74-85 \%$ approximately).

Higher hydrogen yield (HY) of $2.73 \mathrm{~mol}^{-\mathrm{H}_{2}}$ molcarbohydrate $^{-1}$ happened at a HRT of $6 \mathrm{~h}$, possibly due to the high carbohydrate degradation efficiency (Figure 5). HY was approximately constant at HRTs of 4,2 and $1 \mathrm{~h}$, but increased at $0.5 \mathrm{~h}\left(2.43 \mathrm{~mol}^{-\mathrm{H}_{2}}\right.$ mol-

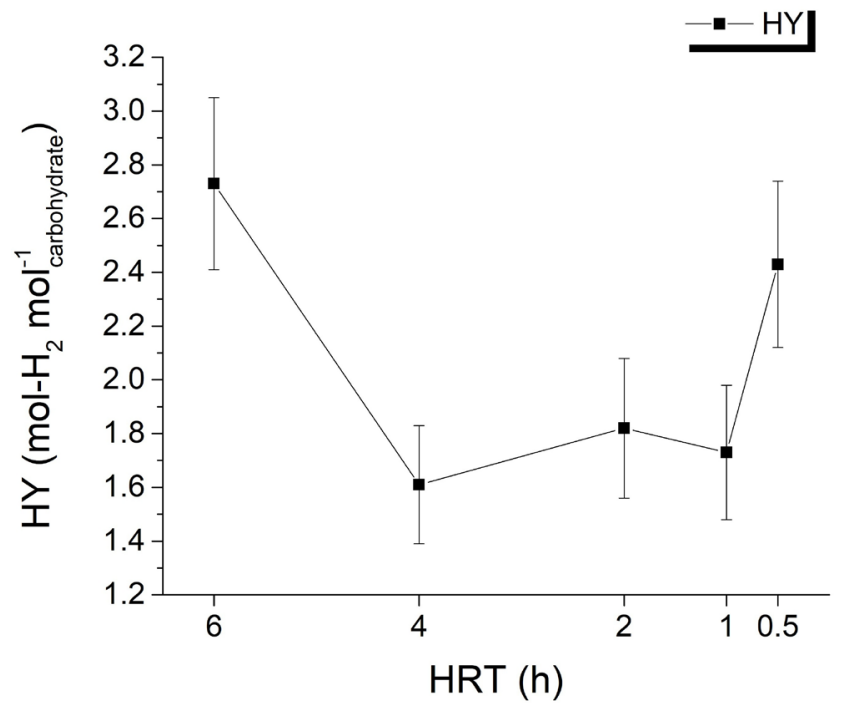

Figure 5. Relation of hydrogen yield relation and HRT. 
carbohydrate $^{-1}$ ). It suggests that a higher influent $\mathrm{pH}$ $(5.1 \pm 0.2)$ benefited the acetic acid production by the microorganisms (Ghimire et al., 2015). The dynamics of microorganisms involved in anaerobic fermentation, producing acids as metabolic by-products, cause constant fluctuations in the $\mathrm{pH}$ within the production system. This drift influences the metabolism of hydrogen-producing bacteria, which could result in the inhibition of product formation (Penniston et al., 2018).

The higher productions of butyric acid in phases 3 and 4 indicated that the increase in the OLR favored the butyric route, which caused a reduction in the HY. This may be related to the deviation of the acetic route in which a greater amount of moles of hydrogen for each mole of carbohydrate consumed is produced in comparison to the production of hydrogen throughout the butyric route. In phase 5 (HRT of $0.5 \mathrm{~h}$ ), the acetic route was favored, probably due to the higher $\mathrm{pH}$, as this operational parameter in the range of $5-6$ optimized acetate production (Jiang et al., 2013; Wang et al., 2014; Wu et al., 2016).

Davila-Vazquez et al. (2009) and Tawfik and Salem (2012) achieved higher HY at lower HRTs (or higher OLRs), inferring that these parameters can present direct or indirect proportional ratio. The $\mathrm{pH}$ range of 5.0-6.0 is referred to as optimum for hydrogen production (Ginkel et al., 2001). Lower $\mathrm{pH}$ values may reduce hydrogen production by inhibiting the activity of the hydrogenase enzyme and neutral $\mathrm{pH}$ may favor the activity of methanogenic microorganisms (Nualsri et al., 2016; Bharathiraja et al., 2016). In this work, although the carbohydrate conversion efficiency reduced from $80 \%$ (phase 6) to $54 \%$ (phase 1), the higher influent $\mathrm{pH}$ of 5.06 contributed to the hydrogen yield at a HRT of $0.5 \mathrm{~h}$.

Silva-Illanes et al. (2017) reported that the HRT influences the composition of subdominant microorganisms, which can interfere in the ability of the consortium and/or the activity of dominant microorganisms to produce hydrogen. Therefore, the reduction of $\mathrm{HY}$ in phases 2, 3 and 4 could be related to the found changes in the metabolic patterns, as demonstrated in the follow analysis of the microbial community.

\section{Analysis of the microbial community}

The dendogram in Figure 6, obtained for each operational phase by PCR-DGGE analysis using primers for the domain Bacteria, shows that the HRT variation modified the microbial structure. Phases 1 and 5 (HRT of 6 and $0.5 \mathrm{~h}$, respectively) had 81\% similarity, justifying the approximate and higher values for $\mathrm{HY}$ of 2.73 and $2.43 \mathrm{~mol}-\mathrm{H}_{2} \mathrm{~mol}^{-1}$-carbohydrate. The hydrogen producer bacterial populations favored acetic and butyric routes in these conditions by the greater conversion of carbohydrates (phase 01 ) and the increase of the $\mathrm{pH}$ to the optimal range for hydrogen

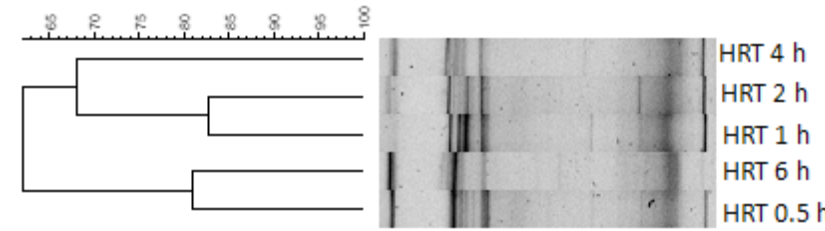

Figure 6. Dendogram from the DGGE profiles obtained in three operational phases of the reactor.

production (phase 05) (Bharathiraja et al., 2016; Elbeshbishyet et al., 2017).

A greater degree of similarity $(83 \%)$ occurred between phases 3 (HRT of $2 \mathrm{~h}$ ) and 4 (HRT of $1 \mathrm{~h}$ ), where caproic acid and n-butanol were produced. In those phases, metabolized acetic acid resulted in butyric and caproic acid formation (Barker et al., 1945; Saady, 2013).

Comparison of phases 2, 3 and 4 with phases 6 and 5 demonstrated a low degree of similarity (63\%). This observation justifies the oscillation in HY (Figure 5), suggesting that microbial activities in HRTs of 6 and $0.5 \mathrm{~h}$ synthetized more hydrogen.

By decreasing the applied HRT from $6 \mathrm{~h}$ to $1 \mathrm{~h}$, an increase was noted in the microbial diversity by the change in the Shannon-Wiener index of diversity varying from 2.030 to 2.586 (Table 2). This can be related to the favoring of other bacterial populations adapted to greater OLR (Silva et al, 2019).

\section{CONCLUSIONS}

Dark fermentative hydrogen production of cheese whey wastewater was investigated using an AFBR reactor under different OLR $\left(12.34-163.02 \mathrm{~kg} / \mathrm{m}^{3} . \mathrm{d}\right)$ at mesophilic temperature. The results showed a reduction in carbohydrate removal efficiency with the OLR increasing given the kinetic limitation on carbohydrate consumption. The maximum HPR $\left(1.4 \pm 0.1 \mathrm{~L}^{-} \mathrm{H}_{2} \mathrm{~h}^{-1}\right.$ $\mathrm{L}^{-1}$-reactor) and hydrogen content in biogas $(52.39 \%)$ were achieved at a HRT of $0.5 \mathrm{~h}$. However, a higher HY of $2.73 \mathrm{~mol}-\mathrm{H}_{2} / \mathrm{mol}$-carbohydrate occurred in a HRT of $6 \mathrm{~h}$ because high efficiency in the degradation of carbohydrate $(80 \%)$ associated with the presence of the highest amount of acetic acid, suggesting that the acetate route benefited the hydrogen yield production. High degree of similarity among microbial communities was observed between phases 01 and $05(80 \%)$ and between phases 03 and 04 (83\%). The decrease in the HRT and, as a consequence, an increase in the OLR caused an augmentation in microbial diversity.

\section{ACKNOWLEDGMENTS}

The authors gratefully acknowledge the financial support of the Brazilian National Council for Scientific and Technological Development (CNPq - In 
Portuguese: Conselho Nacional de Desenvolvimento Científico e Tecnológico).

\section{NOTATION}

AFBR Anaerobic fluidized bed reactor

COD Chemical oxygen demand, (g-COD L $\left.{ }^{-1}\right)$

FID Flame ionization detector

HRT Hydraulic retention time (h)

HY Hydrogen yield (mol- $\mathrm{H}_{2} \mathrm{~mol}^{-1}$-carbohydrate)

OLR Organic loading rate $\left(\mathrm{kg}^{2} \mathrm{COD} \mathrm{m} \mathrm{m}^{-3} \mathrm{~d}^{-1}\right)$

TCD Thermal conductivity detector

VFA Volatile fatty acids $\left(\mathrm{g} \mathrm{L}^{-1}\right)$

HPR Hydrogen production rate $\left(\mathrm{L}-\mathrm{H}_{2} \mathrm{~h}^{-1} \mathrm{~L}^{-1}\right.$-reactor)

VSS Volatile suspended solids $\left(\mathrm{g} \mathrm{L}^{-1}\right)$

\section{REFERENCES}

Abreu, A.A., Alves, J.I., Pereira, M.A., Karakashev, D., Alves, M.M., Angelidaki, I. Engineered heat treated methanogenic granules: A promising biotechnological approach for extreme thermophilic biohydrogen production. Bioresour. Technol., 101, 9577-9586 (2010). https://doi.org/10.1016/j. biortech.2010.07.070

Adorno, M.A.T., Hirasawa, J.S., Varesche, M.B.A. Development and validation of two methods to quantify volatile acids (C2-C6) by GC/FID: Headspace (Automatic and Manual) and liquidliquid extraction (LLE). Am. J. Anal. Chem., 5, 406-414 (2014). https://doi.org/10.4236/ ajac.2014.57049

Akhlaghi, M., Boni, M.R., De Gioannis, G., Muntoni, A., Polettini, A., Pomi, R., Rossi, A., Spiga, D. A parametric response surface study of fermentative hydrogen production from cheese whey. Bioresour. Technol., 244, 473-483 (2017). https://doi. org/10.1016/j.biortech.2017.07.158

Alexandropoulou, M., Antonopoulou, G., Trably, E., Carrere, H., Lyberatos, G. Continuous biohydrogen production from a food industry waste: Influence of operational parameters and microbial community analysis. J. Clean. Prod., 174, 1054-1063 (2018). https://doi.org/10.1016/j.jclepro.2017.11.078

Amorim, E.L.C. de, Barros, A.R., Rissato Zamariolli Damianovic, M.H., Silva, E.L. Anaerobic fluidized bed reactor with expanded clay as support for hydrogen production through dark fermentation of glucose. Int. J. Hydrogen Energy, 34, 783-790 (2009). https://doi.org/10.1016/j. ijhydene.2008.11.007

Amorim, E.L.C. de, Sader, L.T., Silva, E.L., Amorim, E.L.C., Sader, L.T., Silva, E.L. Effect of substrate concentration on dark fermentation hydrogen production using an anaerobic fluidized bed reactor. Appl. Biochem. Biotechnol., 166, 1248-1263 (2012). https://doi.org/10.1007/s12010-011-9511-9
Amorim, N.C.S., Alves, I., Martins, J.S., Amorim, E.L.C. Biohydrogen production from cassava wastewater in an anaerobic fluidized bed reactor. Brazilian J. Chem. Eng., 31, 603-612 (2014). https:// doi.org/10.1590/0104-6632.20140313s00002458

APHA. Standard methods for the examination of water and wastewater, 20th ed. American Public Health Association, American Water Works Association and Water Environmental Federation, Washington DC (1998).

Azbar, N., Çetinkaya Dokgöz, F.T., Keskin, T., Korkmaz,K.S., Syed,H.M.Continuousfermentative hydrogen production from cheese whey wastewater under thermophilic anaerobic conditions. Int. J. Hydrogen Energy, 34, 7441-7447 (2009). https:// doi.org/10.1016/j.ijhydene.2009.04.032

Barker, H.A., Kamen, M.D., Bornstein, B.T. The Synthesis of Butyric and Caproic Acids from Ethanol and Acetic Acid by Clostridium Kluyveri. Proc. Natl. Acad. Sci. U. S. A., 31, 373-381 (1945). https://doi.org/10.1073/pnas.31.12.373

Barros, A.R., Silva, E.L. Hydrogen and ethanol production in anaerobic fluidized bed reactors: Performance evaluation for three support materials under different operating conditions. Biochem. Eng. J., 61, 59-65 (2012). https://doi.org/10.1016/j.bej.2011.12.002

Carrillo-Reyes, J., Celis, L.B., Alatriste-Mondragón, F., Razo-Flores, E. Decreasing methane production in hydrogenogenic UASB reactors fed with cheese whey. Biomass and Bioenergy, 63, 101-108 (2014). https://doi.org/10.1016/J.BIOMBIOE.2014.01.050

Carrillo-Reyes, J., Celis, L.B., Alatriste-Mondragón, F., Razo-Flores, E. Different start-up strategies to enhance biohydrogen production from cheese whey in UASB reactors. Int. J. Hydrogen Energy, 37, 5591-5601 (2012). https://doi.org/10.1016/j. ijhydene.2012.01.004

Castelló, E., García y Santos, C., Iglesias, T., Paolino, G., Wenzel, J., Borzacconi, L., Etchebehere, C. Feasibility of biohydrogen production from cheese whey using a UASB reactor: Links between microbial community and reactor performance. Int. J. Hydrogen Energy, 34, 5674-5682 (2009). https:// doi.org/10.1016/j.ijhydene.2009.05.060

Davila-Vazquez, G., Cota-Navarro, C.B., RosalesColunga, L.M., de León-Rodríguez, A., Razo-Flores, E. Continuous biohydrogen production using cheese whey: Improving the hydrogen production rate. Int. J. Hydrogen Energy, 34, 4296-4304 (2009). https:// doi.org/10.1016/j.ijhydene.2009.02.063

Ding, L., Cheng, J., Qiao, D., Yue, L., Li, Y.Y., Zhou, J., Cen, K. Investigating hydrothermal pretreatment of food waste for two-stage fermentative hydrogen and methane co-production. Bioresour. Technol., 241, 491-499 (2017). https://doi.org/10.1016/j. biortech.2017.05.114 
DuBois, M., Gilles, K.A., Hamilton, J.K., Rebers, P.A., Smith, F. Colorimetric Method for Determination of Sugars and Related Substances. Anal. Chem., 28, 350-356 (1956). https://doi.org/10.1021/ ac60111a017

Ghimire, A., Frunzo, L., Pirozzi, F., Trably, E., Escudie, R., Lens, P.N.L., Esposito, G. A review on dark fermentative biohydrogen production from organic biomass: Process parameters and use of byproducts. Appl. Energy, 144, 73-95 (2015). https:// doi.org/10.1016/j.apenergy.2015.01.045

Guellout, Z., Clion, V., Benguerba, Y., Dumas, C., Ernst, B. Study of the dark fermentative hydrogen production using modified ADM1 models. Biochem. Eng. J., 132, 9-19 (2018). https://doi. org/10.1016/j.bej.2017.12.015

Han, W., Liu, D.N., Shi, Y.W., Tang, J.H., Li, Y.F., Ren, N.Q. Biohydrogen production from food waste hydrolysate using continuous mixed immobilized sludge reactors. Bioresour. Technol., 180, 54-58 (2015). https://doi.org/10.1016/j. biortech.2014.12.067

Inui, M., Vertès, A.A., Yukawa, H. Advanced Fermentation Technologies. Biomass to Biofuels, Wiley Online Books (2010). https://doi. org/10.1002/9780470750025.ch15

Lay, J.J. Modeling and optimization of anaerobic digested sludge converting starch to hydrogen. Biotechnol. Bioeng., 68, 269-278 (2000). https://doi.org/10.1002/(SICI)10970290(20000505)68:3<269::AID-BIT5>3.0.CO;2-T

Liu, B., Xie, G., Wang, R., Xing, D., Ding, J., Zhou, X., Ren, H. Simultaneous hydrogen and ethanol production from cascade utilization of monosubstrate in integrated dark and photo-fermentative reactor. Biotechnology for Biofuels, 8, 1-11 (2015). https://doi.org/10.1186/s13068-014-0191-X

Maintinguer, S.I., Fernandes, B.S., Duarte, I.C.S., Saavedra, N.K., Adorno, M.A.T., Varesche, M.B. Fermentative hydrogen production by microbial consortium. Int. J. Hydrogen Energy, 33, 4309-4317 (2008). https://doi.org/10.1016/j. ijhydene.2008.06.053

Maintinguer, S.I., Sakamoto, I.K., Adorno, M.A.T., Varesche, M.B.A. Bacterial diversity from environmental sample applied to bio-hydrogen production. Int. J. Hydrogen Energy, 40, 3180-3190 (2015). https://doi.org/10.1016/j. ijhydene.2014.12.118

Ottaviano, L.M., Ramos, L.R., Botta, L.S., Varesche, M.B.A., Silva, E.L. Continuous thermophilic hydrogen production from cheese whey powder solution in an anaerobic fluidized bed reactor: Effect of hydraulic retention time and initial substrate concentration. Int. J. Hydrogen Energy, 42, 4848-4860 (2017). https://doi.org/10.1016/j. ijhydene.2016.11.168
Penniston, J., Bosco, E., Kana, G. Impact of medium $\mathrm{pH}$ regulation on biohydrogen production in dark fermentation process using suspended and immobilized microbial cells. Biotechnology \& Biotechnological Equipment, 32, 204-212 (2018). https://doi.org/10.1080/13102818.2017. 1408430

Perna, V., Castelló, E., Wenzel, J., Zampol, C., Fontes Lima, D.M., Borzacconi, L., Varesche, M.B., Zaiat, M., Etchebehere, C. Hydrogen production in an upflow anaerobic packed bed reactor used to treat cheese whey. Int. J. Hydrogen Energy, 38, 54-62 (2013). https://doi. org/10.1016/j.ijhydene.2012.10.022

Rafieenia, R., Pivato, A., Schievano, A., Lavagnolo, M.C. Dark fermentation metabolic models to study strategies for hydrogen consumers inhibition. Bioresour. Technol., 267, 445-457 (2018). https://doi.org/10.1016/j.biortech.2018.07.054

Rai, P.K., Singh, S.P. Integrated dark- and photofermentation: Recent advances and provisions for improvement. Int. J. Hydrogen Energy, 41, 19957-19971 (2016). https://doi.org/10.1016/j. ijhydene.2016.08.084

Ren, N.Q., Chua, H., Chan, S.Y., Tsang, Y.F., Wang, Y.J., Sin, N. Assessing optimal fermentation type for bio-hydrogen production in continuousflow acidogenic reactors. Bioresour. Technol., 98, 1774-1780 (2007). https://doi.org/10.1016/j. biortech.2006.07.026

Rosa, P.R.F., Santos, S.C., Silva, E.L. Different ratios of carbon sources in the fermentation of cheese whey and glucose as substrates for hydrogen and ethanol production in continuous reactors. Int. J. Hydrogen Energy, 39, 1288-1296 (2014). https:// doi.org/10.1016/j.ijhydene.2013.11.011

Saady, N.M.C. Homoacetogenesis during hydrogen production by mixed cultures dark fermentation : Unresolved challenge. Int. J. Hydrogen Energy, 38, 13172-13191 (2013). https://doi. org/10.1016/j.ijhydene.2013.07.122

Silva-Illanes, F., Tapia-Venegas, E., Schiappacasse, M.C., Trably, E., Ruiz-Filippi, G. Impact of hydraulic retention time (HRT) and $\mathrm{pH}$ on dark fermentative hydrogen production from glycerol. Energy, 141, 358-367 (2017). https:// doi.org/10.1016/j.energy.2017.09.073

Silva, A.N. da, Macêdo, W.V., Sakamoto, I.K., Pereyra, D. de L.A.D., Mendes, C.O., Maintinguer, S.I., Caffaro Filho, R.A., Damianovic, M.H.Z., Varesche, M.B.A., Amorim, E.L.C. de. Biohydrogen production from dairy industry wastewater in an anaerobic fluidized-bed reactor. Biomass and Bioenergy, 120, 257-264 (2019). https://doi.org/10.1016/j. biombioe. 2018.11 .025 
Tapia-Venegas, E., Ramirez-Morales, J.E., SilvaIllanes, F., Toledo-Alarcón, J., Paillet, F., Escudie, R., Lay, C.H., Chu, C.Y., Leu, H.J., Marone, A., Lin, C.Y., Kim, D.H., Trably, E., Ruiz-Filippi, G. Biohydrogen production by dark fermentation: scaling-up and technologies integration for a sustainable system. Rev. Environ. Sci. Biotechnol., 14, 761-785 (2015). https://doi.org/10.1007/ s11157-015-9383-5

Tawfik, A., Salem, A. The effect of organic loading rate on bio-hydrogen production from pre-treated rice straw waste via mesophilic up-flow anaerobic reactor. Bioresour. Technol., 107, 186-190 (2012). https://doi.org/10.1016/j.biortech.2011.11.086

Yang, P., Zhang, R., McGarvey, J.A., Benemann, J.R. Biohydrogen production from cheese processing wastewater by anaerobic fermentation using mixed microbial communities. Int. J. Hydrogen Energy, 32, 4761-4771 (2007). https://doi.org/10.1016/j. ijhydene.2007.07.038

Zhang, K., Ren, N., Guo, C., Wang, A., Cao, G. Effects of various pretreatment methods on mixed microflora to enhance biohydrogen production from corn stover hydrolysate. J. Environ. Sci., 23, 1929-1936 (2011). https://doi.org/10.1016/S10010742(10)60679-1

Ziara, R.M.M., Miller, D.N., Subbiah, J., Dvorak, B.I. Lactate wastewater dark fermentation: The effect of temperature and initial $\mathrm{pH}$ on biohydrogen production and microbial community. Int. J. Hydrogen Energy, 44, 661-673 (2018). https://doi. org/10.1016/j.ijhydene.2018.11.045 
